\title{
Three new vanadyl(IV) complexes with non-steroidal anti-inflammatory drugs (Ibuprofen, Naproxen and Tolmetin). Bioactivity on osteoblast-like cells in culture
}

\author{
S.B. Etcheverry ${ }^{\mathrm{a}, \mathrm{b}}$, D.A. Barrio ${ }^{\mathrm{a}}$, A.M. Cortizo ${ }^{\mathrm{a}}$, P.A.M. Williams ${ }^{\mathrm{b}, *}$ \\ ${ }^{a}$ Cátedra de Bioquímica Patológica, Facultad de Cs. Exactas, Universidad Nacional de La Plata, C. Correo 962,1900 La Plata, Argentina \\ ${ }^{\mathrm{b}}$ Centro de Química Inorgánica (CEQUINOR), Facultad de Cs. Exactas, Universidad Nacional de La Plata, C. Correo 962 , 1900 La Plata, \\ Argentina
}

Received 17 April 2001; received in revised form 28 August 2001; accepted 21 September 2001

\begin{abstract}
The synthesis and spectral and magnetic characterization of $\mathrm{VO}^{2+}$ complexes with Ibuprofen (2-(4-isobutylphenyl)propionic acid), Naproxen (6-methoxy- $\alpha$-methyl-2-naphthalene acetic acid) and Tolmetin (1-methyl-5-(4-methylbenzoyl)-1H-pyrrole-2-acetic acid) were studied. The complexes $\left[\mathrm{VO}(\mathrm{Ibu})_{2}\right] \cdot 5 \mathrm{CH}_{3} \mathrm{OH},\left[\mathrm{VO}(\mathrm{Nap})_{2}\right] \cdot 5 \mathrm{CH}_{3} \mathrm{OH}$ and $\left[\mathrm{VO}(\mathrm{Tol})_{2}\right]$ were obtained from methanolic solutions under nitrogen atmosphere. The biological activities of these complexes on the proliferation of two osteoblast-like cells in culture (MC3T3E1 and UMR106) were compared with that of the vanadyl(IV) cation. The complexes exhibited different effects depending on the concentration and the cellular type, while no effect was observed for their parent drugs. (C) 2002 Elsevier Science B.V. All rights reserved.
\end{abstract}

Keywords: Anti-inflammatory drugs; Vanadyl complexes; Spectroscopy; Osteoblast proliferation

\section{Introduction}

It is well known that most of the anti-inflammatory drugs are carboxylic acids in which the carboxylate group is available for metal-ligand interaction [1-3]. Ibuprofen (2-(4-isobutylphenyl)propionic acid), Naproxen (6methoxy- $\alpha$-methyl-2-naphthalene acetic acid) and Tolmetin (1-methyl-5-(4-methylbenzoyl)-1H-pyrrole-2-acetic acid) (see Fig. 1) are non-steroidal anti-inflammatory drugs (NSAIDs) that exhibit favourable anti-inflammatory, analgesic and antipyretic properties. The major clinical application of NSAIDs is their action as anti-inflammatory agents in muscle skeletal diseases [4]. There are a number of recently published papers on the effects of NSAIDs in bone-related tissues under different inflammatory conditions [5-7].

Several transition metal complexes with NSAIDs have been extensively studied since Sorenson [3] demonstrated that copper(II) complexes are more active than their parent

*Corresponding author. Fax: +54-221-425-9485.

E-mail address: williams@dalton.quimica.unlp.edu.ar (P.A.M. Williams). drugs and exhibit an anti-ulcer activity. These complexes show a lower toxicity than the inorganic forms of copper(II). On the other hand, some studies suggest that regular Ibuprofen intake may also be an effective chemopreventive agent against breast cancer and can decrease non-small cell lung cancer growth in vitro [8].

Vanadium is an ultramicrotrace bioelement with interesting biological properties [9-12]. In mammals, vanadium is

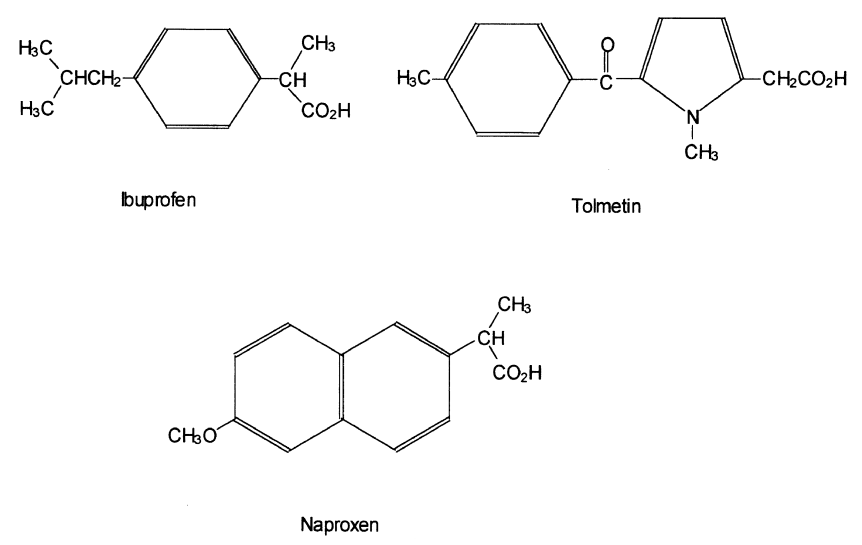

Fig. 1. Structures of Ibuprofen, Naproxen and Tolmetin. 
mainly stored in bones and kidneys [10]. For this reason it is very interesting to study the biological effects of vanadium compounds in bone-related cells. Using an in vitro model of osteoblast-like cells in culture, it has previously been shown that vanadium exerts a biphasic effect: while low concentrations stimulate, high concentrations induce inhibition of osteoblast growth and differentiation as well as morphological transformations [1318].

We have recently reported the synthesis and bioactivity of a new vanadyl(IV)-Aspirin complex (Asp-VO) [19]. This complex seems to be more potent than uncomplexed vanadyl salt in inhibiting the growth of osteoblast-like cells and regulating cell proliferation and differentiation [19]. These effects are partially associated with the ability of vanadium derivatives to indirectly induce phosphorylation in tyrosine residues of proteins by inhibition of protein tyrosine phosphatases (PTPases). In addition, the antineoplastic effects of vanadium have been demonstrated both in vitro and in vivo models. For instance, organometallic complexes of vanadium(IV) linked to bis(cyclopentadienyl) moieties or vanadocenes [20] and oxovanadium compounds that included substituted phenanthroline and $2,2^{\prime}$-bipyridine ligands induce apoptosis in human cancer cells [21].

The aim of this study was the synthesis and characterization of new NSAIDs-vanadyl complexes. Moreover, the effects of these complexes on osteoblast proliferation were determined in two cell lines in culture: the non-transformed MC3T3E1 derived from mouse calvaria and the tumoral UMR106 from a rat osteosarcoma. The results were compared with those for the parent drugs.

\section{Experimental}

\subsection{Materials and methods}

Ibuprofen, Naproxen, Tolmetin (Sigma), and $\mathrm{VOSO}_{4}$ (Merck) were used as supplied. Tissue culture materials were provided by Corning or Falcon. Dulbecco's modified Eagle's medium (DMEM), trypsin, fetal bovine serum (FBS) and ethylenediamine-tetraacetic acid (EDTA) were supplied by Gibco. All other chemicals used were of analytical grade.

Electronic UV-vis and diffuse reflectance spectra were recorded on a Hewlett-Packard 8453 diode-array spectrophotometer and a Shimadzu UV-300 spectrophotometer, respectively. Infrared spectra were recorded on a PerkinElmer 580B spectrophotometer using the $\mathrm{KBr}$ pellet technique. Room temperature magnetic susceptibility was determined with a Cahn-2000 balance, calibrated with $\mathrm{Hg}\left[\mathrm{Co}(\mathrm{SCN})_{4}\right]$ and at a magnetic field strength of $6 \mathrm{kG}$. Elemental analyses for carbon, hydrogen and nitrogen were performed using a Carlo Erba EA 1108 analyzer.

\subsection{Syntheses}

\subsection{1. $\left[\mathrm{VO}(\mathrm{Ibu})_{2}\right] \cdot 5 \mathrm{CH}_{3} \mathrm{OH}$}

A solution of $2 \mathrm{mmol}$ of Ibuprofen in $6 \mathrm{ml} \mathrm{MeOH}$ was added to a methanolic $\operatorname{VOSO}_{4} \cdot 5 \mathrm{H}_{2} \mathrm{O}$ solution $(10 \mathrm{ml}, 1$ $\mathrm{mmol}$ ) under nitrogen atmosphere. The generated precipitate $\mathrm{Na}_{2} \mathrm{SO}_{4}$ was separated by centrifugation and discarded. The violet solution was kept at $-20^{\circ} \mathrm{C}$ overnight. The violet crystals formed were not suitable for X-ray diffraction analysis and their powder diagram showed a highly amorphous character. Recrystallization procedures failed due to decomposition of the samples. Yield: $80 \%$. Anal. Calcd. for $\mathrm{C}_{31} \mathrm{H}_{54} \mathrm{O}_{10} \mathrm{~V}$ : C, $58.4 \%$; H, 8.5\%. Found: C, $58.1 \%$; H, 8.2\%. Room temperature magnetic moment: 1.71 BM. $\mathrm{MW}_{\text {calcd. }}: 637$.

\subsection{2. $\left[\mathrm{VO}(\mathrm{Nap})_{2}\right] \cdot 5 \mathrm{CH}_{3} \mathrm{OH}$}

Naproxen methanolic solution $(2 \mathrm{mmol}, 20 \mathrm{ml})$ was added to a solution of $\operatorname{VOSO}_{4} \cdot 5 \mathrm{H}_{2} \mathrm{O}(1 \mathrm{mmol}$ in $10 \mathrm{ml}$ $\mathrm{MeOH})$ under nitrogen atmosphere. $\mathrm{Na}_{2} \mathrm{SO}_{4}$ precipitated immediately and the suspension was maintained with constant stirring for $24 \mathrm{~h}$ under $\mathrm{N}_{2}$ atmosphere. Precautions were taken to avoid alcohol evaporation. Sodium sulphate was then separated by centrifugation and the final violet solution was kept at $-20^{\circ} \mathrm{C}$ overnight. A grey powder was formed, separated by filtration and washed with cold $\mathrm{MeOH}$. Yield: $60 \%$. Anal. Calcd. for $\mathrm{C}_{33} \mathrm{H}_{46} \mathrm{O}_{12} \mathrm{~V}$ : C, 56.0\%; H, 6.7\%. Found: C, 55.6\%; H, $6.4 \%$. Room temperature magnetic moment: 1.78 BM. $\mathrm{MW}_{\text {calcd. }}: 685$.

\subsection{3. $\left[\mathrm{VO}(\mathrm{Tol})_{2}\right]$}

The same procedure as for Naproxen-VO was performed. The blue solution was kept at $-20^{\circ} \mathrm{C}$. A grey powder was obtained in a few days with poor yield (ca. $10 \%)$. The solid was filtered and washed with cold $\mathrm{MeOH}$. Anal. Calcd. for $\mathrm{C}_{30} \mathrm{H}_{28} \mathrm{~N}_{2} \mathrm{O}_{7} \mathrm{~V}: \mathrm{C}, 62.2 \%$; $\mathrm{H}, 4.8 \%$; N, $4.8 \%$. Found: $\mathrm{C}, 62.5 \%$; H, $5.0 \%$; N, 4.8\%. Room temperature magnetic moment: $1.99 \mathrm{BM} . \mathrm{MW}_{\text {calcd. }}: 579$.

\subsection{Cell culture}

Rat osteosarcoma UMR106 and osteoblastic non-transformed mouse calvaria derived MC3T3E1 cells were grown in DMEM supplemented with $10 \%(\mathrm{v} / \mathrm{v})$ FBS and antibiotics $(100 \mathrm{U} / \mathrm{ml}$ penicillin and $100 \mathrm{mg} / \mathrm{ml}$ streptomycin) in a humidified atmosphere of $95 \%$ air $/ 5 \% \mathrm{CO}_{2}$. Cells were grown at near-confluence (70-80\%) and were subcultured using $0.1 \%$ trypsin-1 mM EDTA in $\mathrm{Ca}^{2+}$ $\mathrm{Mg}^{2+}$-free phosphate-buffered saline (PBS). For experiments, about $5.5 \times 10^{4}$ cells $/$ well (UMR 106) and $3.3 \times 10^{4}$ cells/well (MC3T3E1) were plated onto 24-well plates. After the culture reached $70 \%$ confluence, the cells were washed twice with DMEM. Cells were incubated overnight with vanadium compounds at different doses in serum-free DMEM. 


\subsection{Cell proliferation assay}

A mitogenic bioassay was carried out as described by Okajima et al. [22] with some modifications. Briefly, cells in 24-well plates were washed with PBS and fixed with 5\% glutaraldehyde/PBS at room temperature for $10 \mathrm{~min}$. Cells were then stained with $0.5 \%$ crystal violet $/ 25 \%$ methanol for $10 \mathrm{~min}$. The dye solution was then discarded and the plate was washed with water and dried. The dye in the cells was extracted using $0.5 \mathrm{ml} /$ well $0.1 \mathrm{M}$ glycine $/ \mathrm{HCl}$ buffer, $\mathrm{pH} 3.0 / 30 \%$ methanol and transferred to test tubes. Absorbance was read at $540 \mathrm{~nm}$ after a convenient sample dilution. The correlation between cell number/well and the absorbance at $540 \mathrm{~nm}$ of diluted extraction sample after crystal violet staining has been established previously [14]. Data are expressed as the mean \pm S.E.M. Statistical differences were analyzed using Student's $t$-test. $t$-Tests were performed to compare treated cultures with the untreated cultures. The recently prepared vanadyl(IV) complexes were used to obtain fresh solutions to be added to the culture dishes at the following concentrations: $0,2.5,5,10$, $25,50,75$ and $100 \mu \mathrm{M}$. The studies were performed in this concentration range because we and other authors have demonstrated that higher concentrations of vanadium compounds are toxic and cause osteoblast death [18].

\section{Results and discussion}

\subsection{UV-vis spectra}

The UV-vis spectra were recorded in methanolic solutions (see Table 1, $\mathrm{L} / \mathrm{M}=2: 1$ ). Using the well-known Ballhausen and Gray MO scheme for $\mathrm{C}_{4 \mathrm{v}}$ symmetry [23], the ligand field transitions in $\left[\mathrm{VO}\left(\mathrm{H}_{2} \mathrm{O}\right)_{5}\right]^{2+}$ can be assigned as follows: the band at lower energies corresponds to the $b_{2} \rightarrow e$ transition and the second band to the

Table 1

$\mathrm{UV}-\mathrm{vis}$ and diffuse reflectance spectra of $\left[\mathrm{VO}(\mathrm{Ibu})_{2}\right] \cdot 5 \mathrm{CH}_{3} \mathrm{OH}$, $\left[\mathrm{VO}(\mathrm{Nap})_{2}\right] \cdot 5 \mathrm{CH}_{3} \mathrm{OH}$ and $\left[\mathrm{VO}(\mathrm{Tol})_{2}\right]$

\begin{tabular}{lll}
\hline & $\mathrm{b}_{2} \rightarrow \mathrm{e}$ & $\mathrm{b}_{2} \rightarrow \mathrm{b}_{1}$ \\
\hline Ibu-VO & $845(25)^{\mathrm{a}, \mathrm{b}}$ & $595(14.5)^{\mathrm{a}, \mathrm{b}}$ \\
& $840^{\mathrm{c}}$ & $565^{\mathrm{c}}$ \\
& {$[820]$} & {$[570]$} \\
Nap-VO & $840(17)^{\mathrm{b}}$ & $620(10.2)^{\mathrm{b}}$ \\
& $850^{\mathrm{c}}$ & $565^{\mathrm{c}}$ \\
Tol-VO & {$[810]$} & {$[560]$} \\
& $835(20.5)^{\mathrm{b}}$ & $610(16)^{\mathrm{b}}$ \\
& $850^{\mathrm{c}}$ & $570^{\mathrm{c}}$ \\
& {$[840]$} & {$[550]$} \\
\hline
\end{tabular}

Electronic absorption bands in $\mathrm{nm}$; absorptivity $\left(\mathrm{M}^{-1} \mathrm{~cm}^{-1}\right)$ in parentheses; diffuse reflectance in brackets.

${ }^{a}$ Ref. [25].

${ }^{\mathrm{b}}$ Methanolic solutions.

${ }^{\mathrm{c}}$ Cell culture medium solutions. $\mathrm{b}_{2} \rightarrow \mathrm{b}_{1}$ transition. The shift of the $\mathrm{b}_{2} \rightarrow \mathrm{e}$ and $\mathrm{b}_{2} \rightarrow \mathrm{b}_{1}$ bands to the red and blue, respectively, compared with that of $\left[\mathrm{VO}\left(\mathrm{H}_{2} \mathrm{O}\right)_{5}\right]^{2+}$, agrees with carboxylate coordination to the metal center [24,25]. For the bioactivity studies the solid complexes were dissolved in culture medium and added in different concentrations to the cell monolayer. For this reason, the UV-vis spectra in DMEM medium for the three complexes were measured. Table 1 shows the electronic absorption bands of the complexes dissolved in the cell culture medium. The solutions were prepared $10^{3}$ times more concentrated than those used for biological assays, in a L/M molar ratio of 5:1. These conditions were selected to allow detection by UV-visible electronic spectroscopy and to reduce hydrolysis effects. These spectra remain unchanged for $2 \mathrm{~h}$. This period was chosen because it is sufficient for cellular uptake of the complexes. Inside the cells, the compounds are metabolised and the nature of the biologically active species is not fully understood [15]. The diffuse reflectance spectra of the three solid complexes show the same pattern (Table 1). The differences observed in the positions of the band maxima can be attributed to solvatochromic effects. Nevertheless, the above shifts are a general pattern observed in both types of solutions and in the solid state, suggesting the same structure for the complexes under the three experimental conditions.

Table 2

Infrared spectra of Ibuprofen, its sodium salt and the complex with VO(IV)

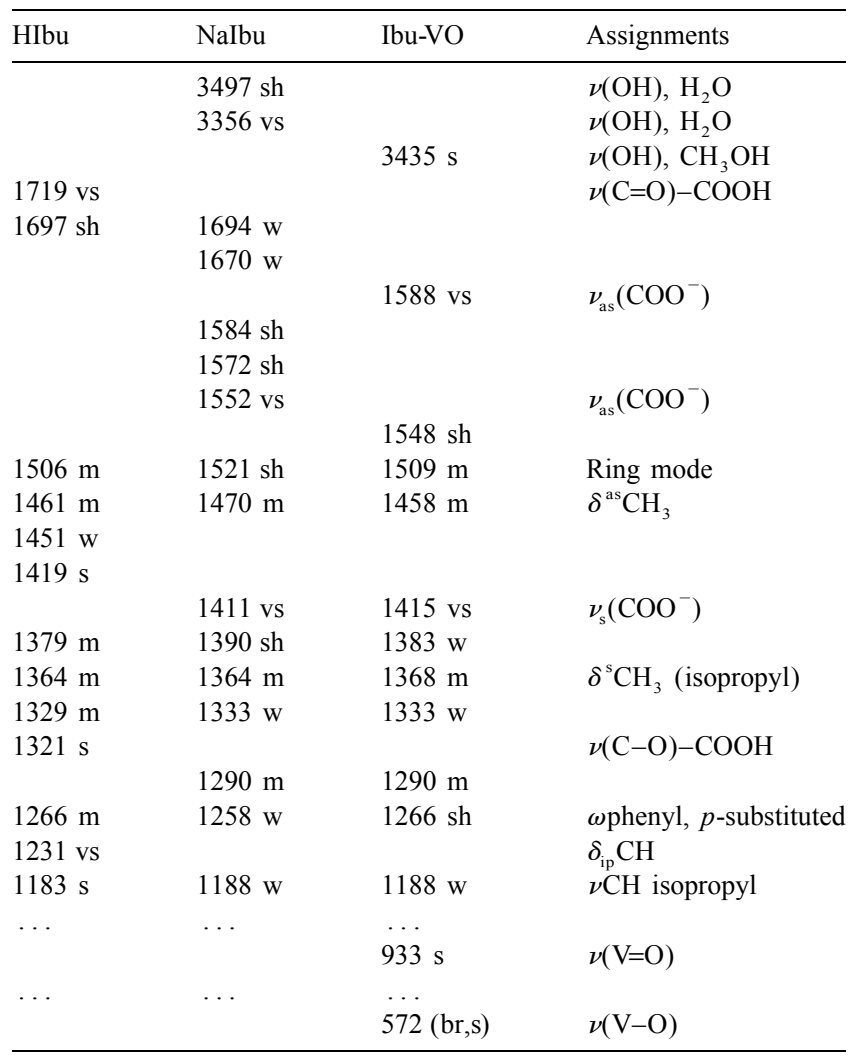

vs, very strong; s, strong; m, medium; w, weak; sh, shoulder; br, broad. 


\subsection{Infrared spectra}

The most important features of the infrared spectra of the three complexes and the corresponding free ligands are shown in Tables $2-4$.

The $\mathrm{O}-\mathrm{H}$ stretchings due to water or methanol can be observed in the $3600-3300 \mathrm{~cm}^{-1}$ range.

The $\nu(\mathrm{C}=\mathrm{O})$ of the carboxylic acid group appeared at ca. $1730-1720 \mathrm{~cm}^{-1}$ for the free ligands. The assignments of IR frequencies for the antisymmetric $\nu_{\mathrm{as}}\left(\mathrm{COO}^{-}\right)$and symmetric $\nu_{\mathrm{s}}\left(\mathrm{COO}^{-}\right)$stretching vibrations for the sodium salts and the complexes are given in the tables. The positions of these bands for the sodium salts and the separation between them $\left(\Delta \mathrm{ca} .146 \mathrm{~cm}^{-1}\right)$ are consistent with an anionic carboxylate group. In the complexes, $\nu_{\text {as }}\left(\mathrm{COO}^{-}\right)$occurs at $\sim 1590 \mathrm{~cm}^{-1}$ and $\nu_{\mathrm{s}}\left(\mathrm{COO}^{-}\right)$at $\sim 1412$ $\mathrm{cm}^{-1}$ with an average $\Delta \nu$ value of $\sim 178 \mathrm{~cm}^{-1}$. The correlations between the $\Delta \nu$ values and the carboxylate mode of bonding are essentially empirical [26]. For comparative purposes, in the case of metal complexes with carboxylate ligands other than acetates, it is important to consider the $\Delta \nu$ values of similar metallic complexes with known crystalline structures [27-31].

Table 3

Infrared spectra of Naproxen, its sodium salt and the complex with VO(IV)

\begin{tabular}{|c|c|c|c|}
\hline HNap & NaNap & Nap-VO & Assignments \\
\hline & $3465 \mathrm{br}$ & & $\nu(\mathrm{OH}), \mathrm{H}_{2} \mathrm{O}$ \\
\hline & $3371 \mathrm{br}$ & & $\nu(\mathrm{OH}), \mathrm{H}_{2} \mathrm{O}$ \\
\hline & & 3452 br & $\nu(\mathrm{OH}), \mathrm{CH}_{3} \mathrm{OH}$ \\
\hline \multirow[t]{2}{*}{1729 vs } & & & $\nu(\mathrm{C}=\mathrm{O})-\mathrm{COOH}$ \\
\hline & $1700 \mathrm{w}$ & $1709 \mathrm{w}$ & \\
\hline \multicolumn{4}{|l|}{$1687 \mathrm{~m}$} \\
\hline $1631 \mathrm{w}$ & $1631 \mathrm{w}$ & $1633 \mathrm{w}$ & \\
\hline \multirow[t]{2}{*}{$1606 \mathrm{~m}$} & $\begin{array}{l}1606 \mathrm{~m} \\
1562 \mathrm{~s}\end{array}$ & $1605 \mathrm{sh}$ & \\
\hline & 1550 vs & 1592 vs & $\nu_{\mathrm{as}}\left(\mathrm{COO}^{-}\right)$ \\
\hline $1507 \mathrm{w}$ & $1502 \mathrm{w}$ & $1506 \mathrm{w}$ & Ring mode \\
\hline $1482 \mathrm{w}$ & $\begin{array}{l}1485 \mathrm{w} \\
1471 \mathrm{w}\end{array}$ & $1484 \mathrm{w}$ & \\
\hline \multirow{2}{*}{$\begin{array}{l}1453 \mathrm{w} \\
1419 \mathrm{w}\end{array}$} & $1453 \mathrm{w}$ & $1461 \mathrm{~m}$ & $\delta^{\text {as }} \mathrm{CH}_{3}$ \\
\hline & $1404 \mathrm{~m}$ & $1412 \mathrm{~s}$ & $\nu_{\mathrm{s}}\left(\mathrm{COO}^{-}\right)$ \\
\hline \multirow[t]{2}{*}{$1395 \mathrm{~m}$} & $1393 \mathrm{~m}$ & $1392 \mathrm{~m}$ & $\delta^{\mathrm{s}} \mathrm{CH}_{3}$ (isopropyl) \\
\hline & $1364 \mathrm{~m}$ & $1369 \mathrm{w}$ & $\delta^{\mathrm{s}} \mathrm{CH}_{3}$ (isopropyl) \\
\hline \multirow[t]{2}{*}{$1347 \mathrm{~m}$} & $1341 \mathrm{w}$ & $1346 \mathrm{w}$ & $\nu(\mathrm{C}-\mathrm{O})-\mathrm{COOH}$ \\
\hline & $1304 \mathrm{w}$ & & \\
\hline $1268 \mathrm{~m}$ & $\begin{array}{l}1265 \mathrm{~m} \\
1248 \mathrm{~m}\end{array}$ & $1268 \mathrm{~m}$ & \\
\hline \multirow[t]{2}{*}{$1229 \mathrm{~m}$} & $1231 \mathrm{w}$ & $1230 \mathrm{~m}$ & $\delta_{\mathrm{ip}} \mathrm{CH}$ \\
\hline & $1215 \mathrm{~s}$ & $1214 \mathrm{~m}$ & \\
\hline $1196 \mathrm{~m}$ & & $1197 \mathrm{w}$ & $\nu \mathrm{CH}$ isopropyl \\
\hline $1178 \mathrm{~s}$ & & $1175 \mathrm{~m}$ & \\
\hline $1161 \mathrm{~s}$ & $1162 \mathrm{~m}$ & $1158 \mathrm{~m}$ & \\
\hline$\cdots$ & $\cdots$ & ‥ & $\nu(\mathrm{V}=\mathrm{O})$ \\
\hline$\cdots$ & $\cdots$ & $\begin{array}{l}\ldots \\
572 \mathrm{~m}\end{array}$ & $\nu(\mathrm{V}-\mathrm{O})$ \\
\hline
\end{tabular}

vs, very strong; s, strong; m, medium; w, weak; sh, shoulder; br, broad.
Table 4

Infrared spectra of Tolmetin, its sodium salt and the complex with VO(IV)

\begin{tabular}{|c|c|c|c|}
\hline HTol & NaTol & Tol-VO & Assignments \\
\hline & $3514 \mathrm{br}$ & & $\nu(\mathrm{OH}), \mathrm{H}_{2} \mathrm{O}$ \\
\hline $1732 \mathrm{~s}$ & & & $\nu(\mathrm{C}=\mathrm{O})-\mathrm{COOH}$ \\
\hline \multirow[t]{2}{*}{$1701 \mathrm{vs}$} & & & $\nu(\mathrm{C}=\mathrm{O})$ \\
\hline & $1678 \mathrm{~m}$ & $1665 \mathrm{sh}$ & $\nu(\mathrm{C}=\mathrm{O})$ \\
\hline $1630 \mathrm{sh}$ & $1640 \mathrm{w}$ & & \\
\hline 1617 vs & $1612 \mathrm{~m}$ & $1610 \mathrm{sh}$ & \\
\hline \multicolumn{4}{|l|}{$1605 \mathrm{sh}$} \\
\hline & $1597 \mathrm{~s}$ & & \\
\hline & $1565 \mathrm{~m}$ & 1590 vs & $\nu_{\text {as }}\left(\mathrm{COO}^{-}\right)$ \\
\hline $1488 \mathrm{~m}$ & $1489 \mathrm{~m}$ & $1490 \mathrm{~m}$ & Ring mode \\
\hline $1459 \mathrm{~m}$ & $1452 \mathrm{~m}$ & $1455 \mathrm{~s}$ & $\delta^{\text {as }} \mathrm{CH}_{3}$ \\
\hline $1428 \mathrm{w}$ & & $1430 \mathrm{~m}$ & \\
\hline & $1414 \mathrm{~m}$ & $1410 \mathrm{~s}$ & $\nu_{\mathrm{s}}\left(\mathrm{COO}^{-}\right)$ \\
\hline \multicolumn{4}{|l|}{$1407 \mathrm{w}$} \\
\hline \multirow[t]{5}{*}{$1377 \mathrm{~m}$} & $1379 \mathrm{sh}$ & $1375 \mathrm{~s}$ & $\begin{array}{l}\nu(\mathrm{C}-\mathrm{O})-\mathrm{COOH}, \\
\delta^{\mathrm{s}} \mathrm{CH}_{3}\end{array}$ \\
\hline & $1369 \mathrm{~s}$ & & \\
\hline & $1341 \mathrm{~m}$ & & \\
\hline & $1306 \mathrm{w}$ & & \\
\hline & $1281 \mathrm{~s}$ & $1291 \mathrm{~m}$ & \\
\hline $1268 \mathrm{~m}$ & & $1266 \mathrm{~s}$ & $\omega$ phenyl, $p$-substituted \\
\hline $1237 \mathrm{~m}$ & $1228 \mathrm{w}$ & $1237 \mathrm{~s}$ & $\delta_{\mathrm{ip}} \mathrm{CH}$ \\
\hline $1196 \mathrm{w}$ & $1191 \mathrm{~m}$ & $1194 \mathrm{~m}$ & \\
\hline $1178 \mathrm{~m}$ & $1179 \mathrm{~m}$ & $1181 \mathrm{~m}$ & $\nu \mathrm{CH}$ \\
\hline $1155 \mathrm{~m}$ & $1155 \mathrm{~m}$ & $1155 \mathrm{~m}$ & \\
\hline $1131 \mathrm{w}$ & $1131 \mathrm{~m}$ & & \\
\hline \multirow[t]{2}{*}{$\ldots$} & $\ldots$ & $\cdots$ & \\
\hline & & $943 \mathrm{~s}$ & $\nu(\mathrm{V}=\mathrm{O})$ \\
\hline$\cdots$ & $\cdots$ & $\begin{array}{c}\ldots \\
545 \mathrm{~m}\end{array}$ & $\nu(\mathrm{V}-\mathrm{O})$ \\
\hline
\end{tabular}

vs, very strong; s, strong; m, medium; w, weak; sh, shoulder; br, broad.

The stretching frequencies $\nu(\mathrm{V}=\mathrm{O})$ are located at ca. 940 $\mathrm{cm}^{-1}$ for the three complexes. Complexes of vanadyl(IV) cation with monodentate carboxylate ligands exhibit this frequency at higher values [31]. On the other hand, for polymeric chains in which the $\mathrm{V}=\mathrm{O}$ moieties are held together by double acetate bridges, $\nu(\mathrm{V}=\mathrm{O})$ is $<900 \mathrm{~cm}^{-1}$. In these complexes, there is an interaction involving the $\mathrm{V}-\mathrm{O}$ bond itself and the neighbouring oxometal units [32-36]. In the case of a coordination sphere around the vanadium atom consisting of two chelate-sugar moieties ligated through deprotonated hydroxyl atoms, the position of the stretching frequencies are ca. $940-930 \mathrm{~cm}^{-1}$ $[37,38]$. This suggests that the vanadyl complexes reported here present the same type of chelate environment around the metal center.

The $\mathrm{V}-\mathrm{O}$ stretchings are located between 570 and 545 $\mathrm{cm}^{-1}$.

For Tolmetin, $\nu(\mathrm{C}=\mathrm{O})$ of the carbonyl group is located at $1701 \mathrm{~cm}^{-1}$ for the free acid. This band is very sensitive when electron donor or electron acceptor groups are attached to the ligand [39]. As expected, when the ligand is deprotonated (as in the sodium salt) or coordinated to vanadium, this band shifts to 1678 and $1665 \mathrm{~cm}^{-1}$, respectively. 


\subsection{Magnetic behaviour}

Measurements of the room temperature magnetic moments are good criteria to determine whether the carboxylate anion is acting as a bridge or chelate ligand. Subnormal $\mu_{\text {eff }}$ values are indicative of the coupling between metal ions as in the case of copper(II)-carboxylate adducts of the type $\left[\mathrm{Cu}(\mathrm{RCOO})_{2} \mathrm{~L}\right]_{2} \quad[30,40]$. For NSAIDs-vanadyl complexes, the measured $\mu_{\text {eff }}$ are in the range 1.71-1.99 $\mathrm{BM}$, in accordance with the values expected for a $\mathrm{d}^{1}(s=1 / 2)$ system. When coupling between oxovanadium(IV) centers occurs, the room temperature $\mu_{\text {eff }}$ values are lower [32-36]. Based on these results, carboxylate bridging coordination has to be discarded.

\subsection{Effect of NSAIDs-vanadyl(IV) complexes on osteoblast growth}

The free ligands, Ibuprofen, Naproxen and Tolmetin were tested on both osteoblast-like cell lines in the concentration range $0-100 \mu \mathrm{M}$. These drugs did not inhibit or promote cell proliferation in the tested concentration range. No statistical differences were observed in comparison with the basal condition, without vanadium compounds (data not shown).

On the other hand, the effects of the NSAIDs-VO(IV) complexes on non-transformed mouse calvaria MC3T3E1 and UMR106 rat osteosarcoma-derived cells are shown in Fig. 2(A) $-(\mathrm{C})$.
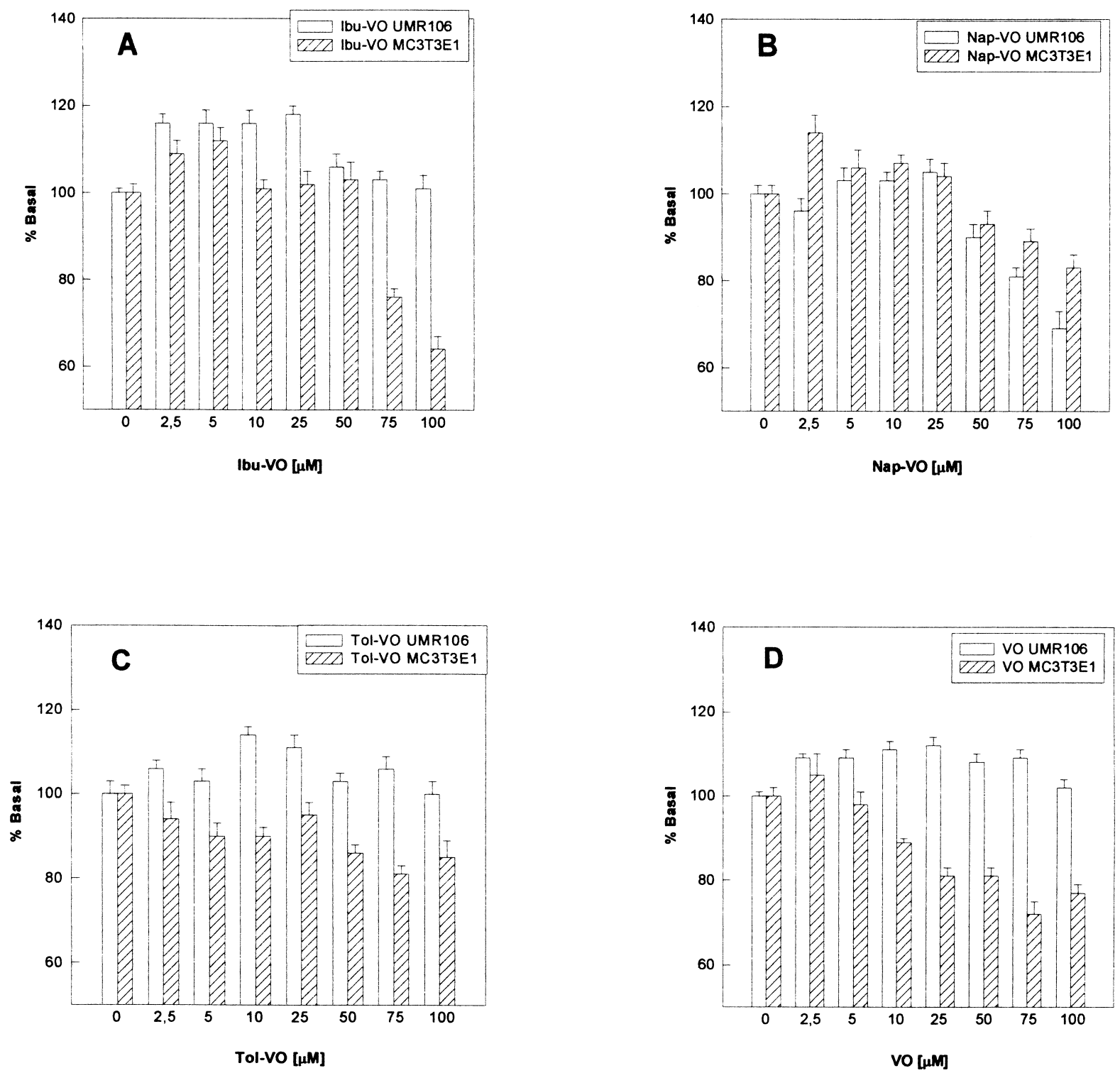

Fig. 2. Effects of Ibu-VO (A), Nap-VO (B), Tol-VO (C) and VO (D) on MC3T3E1 and UMR106 osteoblast-like cell proliferation. Values are expressed as a percentage of the basal value and represent the mean \pm S.E.M. $(n=9)$. Basal values $(0 \mu \mathrm{M}$ vanadyl complexes $)$ are $3.3 \times 10^{4}$ cells $/$ well for MC3T3E1 and $5.5 \times 10^{4}$ cells $/$ well for UMR106 cells. For statistically significant differences, see text. 
MC3T3E1 cells: as can be seen, Ibu-VO (Fig. 2(A)) caused a biphasic effect in cell proliferation, being stimulatory at lower concentrations $(2.5$ and $5 \mu \mathrm{M}, P<$ $0.01)$ and cytotoxic at higher concentrations (75 and 100 $\mu \mathrm{M}, P<0.01$ ). Nap-VO (Fig. 2(B)) also behaved in a similar way, producing stimulation and inhibition of cell proliferation at concentrations of $2.5 \mu \mathrm{M}(P<0.01)$ and $75-100 \mu \mathrm{M}(P<0.01)$, respectively. On the contrary, the complex Tol-VO (Fig. 2(C)) significantly inhibited the growth of MC3T3E1 cells at all the tested concentrations $(P<0.01)$ in a dose-response manner.

UMR106 cells: Ibu-VO (Fig. 2(A)) significantly stimulated cell growth in a narrow range of concentrations (2.5 $-25 \mu \mathrm{M}, P<0.01)$ and showed no significant effects at higher values. Nap-VO (Fig. 2(B)) did not stimulate cell growth at low doses, but it was the more potent cytotoxic agent $(P<0.01)$ at $50-100 \mu \mathrm{M}$ concentrations. This effect was even stronger than in MC3T3E1 non-transformed cells. On the other hand, Tol-VO (Fig. 2(C)) did not show any statistically significant effect in the whole range of concentrations in the UMR106 cell line.

In order to investigate further the Nap-VO-induced cytotoxic effect in both osteoblast cell lines, additional experiments were performed in the $50-100 \mu \mathrm{M}$ concentration range. As can be seen from Fig. 3, this vanadium(IV) derivative was the most potent inhibitor of cell growth in osteosarcoma cells. This effect contrasts with the cytotoxic effect of most of the vanadium(IV) complexes that we have previously reported in these two cell lines, such as VO, BMOV and Asp-VO [16-19]. In those studies the non-transformed cell line was always

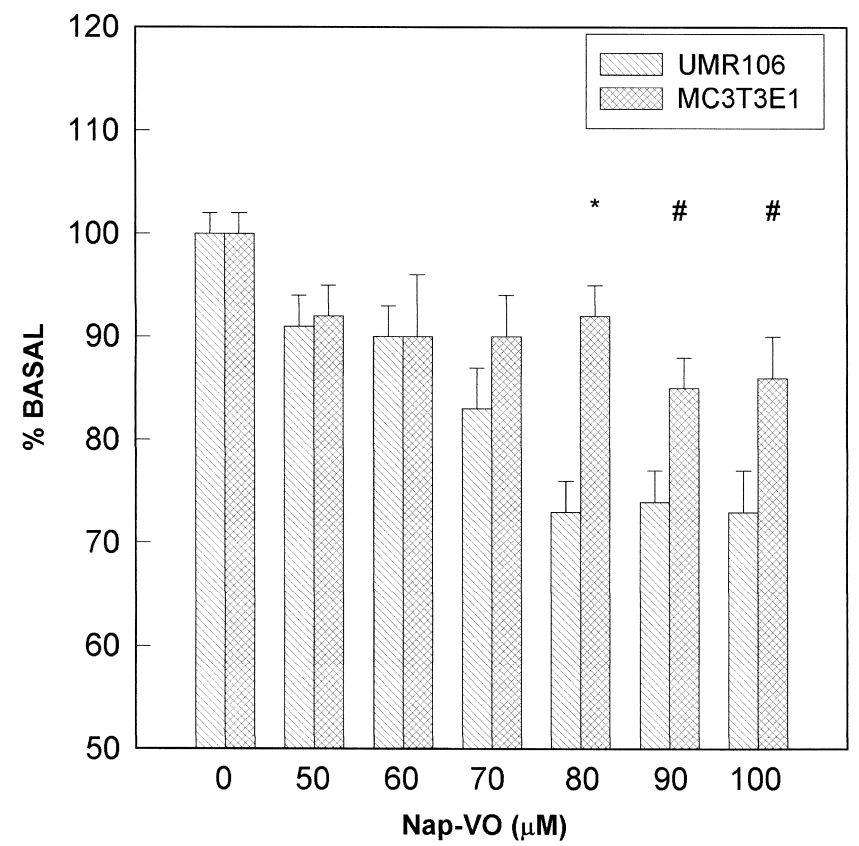

Fig. 3. Effects of Nap-VO on UMR106 and MC3T3E1 cell proliferation. Values are expressed as a percentage of the basal value and represent the mean \pm S.E.M. $(n=6) . * P<0.001, \# P<0.05$. more sensitive to vanadium derivatives than the osteosarcoma UMR106 cells.

The proliferative effect of vanadium(IV) complexes was also compared with the effect of the vanadium(IV) cation on both cell lines (Fig. 2(D)). The addition of VO(IV) to the culture media induced a significant stimulation of UMR106 cell proliferation at $2.5-75 \mu \mathrm{M}(P<0.01)$. On the contrary, in MC3T3E1 non-transformed cells, VO(IV) inhibited cell growth in a dose-response manner (Fig. 2(D)). Another NSAID-VO derivative, the Asp-VO complex [19], also exerted a biphasic effect on UMR106 cells. This complex stimulated cell growth at low doses (2.5-25 $\mu \mathrm{M})$ and inhibited at over $50 \mu \mathrm{M}$ concentration. In addition, Asp-VO, like VO(IV), significantly inhibited MC3T3E1 cells at all the tested concentrations.

\section{Conclusions}

Three new vanadyl(IV) complexes with non-steroidal anti-inflammatory drugs, Ibuprofen, Naproxen, and Tolmetin, were synthesized and characterized by means of elemental analysis, UV-vis, diffuse reflectance and IR spectroscopies, as well as their magnetic behavior. The biological activity of these vanadium compounds was tested on two osteoblast-like cells in culture through a proliferation bioassay. Neither Tolmetin nor Tol-VO affected the UMR106 osteosarcoma cell growth. In nontransformed cells, the complex inhibits cell proliferation in a manner dependent on the concentration. This effect was similar to that induced by $\mathrm{VO}(\mathrm{IV})$. Ibu-VO was a stimulatory agent at low concentrations for both cell lines. However, this complex was cytotoxic at high doses for MC3T3E1 cells. On the other hand, Nap-VO only stimulated MC3T3E1 growth at the lower doses tested without induction of proliferation in UMR106 cells. Above $50 \mu \mathrm{M}$, this complex was cytotoxic to both cell lines. Surprisingly, Nap-VO-induced cell inhibition was more pronounced in UMR106 than in MC3T3E1 cells. The results of the biological assays show that NSAIDs moderate vanadyl(IV) action on osteoblast-like cells. Further experiments are in progress in order to investigate the anti-carcinogenic potential of Nap-VO in other tumoral cell lines.

\section{Acknowledgements}

S.B.E. is a member of the Carrera del Investigador CONICET; A.M.C. and P.A.M.W. are members of the Carrera del Investigador CICPBA and D.A.B. is a fellow of the Colegio de Farmacéuticos de la Provincia de Buenos Aires, Argentina. This study was partially supported by Agencia Nacional de Promoción Científica y Tecnológica (PICT 0606148 and 00375), CONICET (PIP 1044/98), Colegio de Farmacéuticos PBA, CICPBA and UNLP. 


\section{References}

[1] J.R. Sorenson, J. Med. Chem. 19 (1976) 135-148.

[2] US Pat. No. 5082834 (1992).

[3] J.R. Sorenson, in: H. Sigel (Ed.), Metal Ions in Biological Systems, Vol. 14, M. Dekker, New York, 1982, pp. 77-124.

[4] A. Goodman Gilman (Ed.), 9th Edition, Las Bases Farmacológicas de la Terapéutica, Vol. II, McGraw-Hill Interamericana, Méjico, 1996, pp. 661-706.

[5] D.W. Gilroy, A. Tomlinson, K. Greenslade, M.P. Seed, D.A. Willoughby, Inflammation 22 (1998) 509-519.

[6] J.P. Pelletier, Osteoarthritis Cartilage 7 (1999) 374-376.

[7] Z. Szekanecz, E. Szekanecz, K. Morvai, T. Szegedi, I. Sziklai, Orv. Hetil. 140 (1999) 2435-2440.

[8] A. Andrade, S.F. Namora, R.G. Woisky, G. Wiezel, R. Najjar, J.A.A. Sertié, D. de Oliveira Silva, J. Inorg. Biochem. 81 (2000) 23-27.

[9] N.D. Chasteen (Ed.), Vanadium in Biological Systems, Kluwer, Dordrecht, 1990.

[10] H. Sigel, A. Sigel (Eds.), Vanadium and its Role in Life, Metal Ions in Biological Systems, Vol. 31, Marcel Dekker, New York, 1995.

[11] D. Rehder, Biometals 5 (1992) 3-12.

[12] D. Rehder, Coord. Chem. Rev. 182 (1999) 297-322.

[13] A.M. Cortizo, M. Caporossi, G. Lettieri, S.B. Etcheverry, Eur. J. Pharmacol. 400 (2000) 279-285.

[14] A.M. Cortizo, S.B. Etcheverry, Mol. Cell. Biochem. 145 (1995) 97-102.

[15] S.B. Etcheverry, D.C. Crans, A.D. Keramidas, A.M. Cortizo, Arch. Biochem. Biophys. 338 (1997) 7-14.

[16] D.A. Barrio, M.D. Braziunas, S.B. Etcheverry, A.M. Cortizo, J. Trace Elem. Med. Biol. 11 (1997) 110-115.

[17] V.C. Sálice, A.M. Cortizo, C.L. Gómez Dumm, S.B. Etcheverry, Mol. Cell. Biochem. 198 (1999) 119-128.

[18] A.M. Cortizo, L. Bruzzone, S. Molinuevo, S.B. Etcheverry, Toxicology 147 (2000) 89-99.

[19] S.B. Etcheverry, P.A.M. Williams, D.A. Barrio, V.C. Sálice, E.G. Ferrer, A.M. Cortizo, J. Inorg. Biochem. 80 (2000) 169-171.

[20] C. Djordjevic, Antitumor activity of vanadium compounds, in: H. Sigel, A. Sigel (Eds.), Metal Ions in Biological Systems, Vol. 31, M. Dekker, New York, 1995, pp. 595-616.
[21] R.K. Narla, Y. Dong, O.J. D’Cruz, C. Navara, F.M. Ucrun, Clin. Cancer Res. 6 (2000) 1546-1556.

[22] T. Okajima, K. Nakamura, H. Zhang, N. Ling, T. Tanabe, T. Yasuda, R.G. Rozenfeld, Endocrinology 130 (1992) 2201-2212.

[23] C.J. Ballhausen, H.B. Gray, Inorg. Chem. 1 (1962) 111-122.

[24] Y. Allegretti, E.G. Ferrer, A.C. González Baró, P.A.M. Williams, Polyhedron 19 (2000) 2613-2619, and references therein.

[25] P.A.M. Williams, P. Kögerler, E.J. Baran, Acta Farm. Bonaerense 17 (1998) 31-34.

[26] G.B. Deacon, R.J. Phillips, Coord. Chem. Rev. 33 (1980) 227-250.

[27] D.R. Frazier, S.K. Lynch, G.O. Carlisle, J. Inorg. Nucl. Chem. 43 (1981) 2747-2748.

[28] C. Dendrinou-Samara, D.P. Kessissoglou, G.E. Manoussakis, D. Mentzafos, A. Terzis, J. Chem. Soc., Dalton Trans. (1990) 959-965.

[29] Z.N. Chen, R.W. Deng, J.G. Wu, J. Inorg. Biochem. 47 (1992) 81-87.

[30] A.L. Abuhijleh, J. Inorg. Biochem. 55 (1994) 255-262, and references therein.

[31] C. Dendrinou-Samara, G. Tsotsou, L.V. Ekateriniadou, A.M. Kotsaris, C.P. Raptopoulou, A. Terzis, D.M. Kyriakidis, D.P. Kessissoglou, J. Inorg. Biochem. 71 (1998) 171-179.

[32] A.T. Casey, J.R. Thackeray, Aust. J. Chem. 22 (1969) 2549-2553.

[33] V.T. Kalinnikov, V.V. Zelentsov, O.N. Kuz'micheva, T.G. Aminov, Russ. J. Inorg. Chem. 15 (1970) 341-343.

[34] A.T. Casey, B.S. Morris, E. Sinn, J.R. Thackeray, Aust. J. Chem. 25 (1972) 1195-1205.

[35] B.G. Bennet, D. Nicholls, J. Inorg. Nucl. Chem. 34 (1972) 673-677.

[36] J.P. Walter, M. Dartiguenave, Y. Dartiguenave, J. Inorg. Nucl. Chem. 35 (1973) 3207-3217.

[37] S.B. Etcheverry, P.A.M. Williams, E.J. Baran, Carbohydr. Res. 302 (1997) 131-138.

[38] P.A.M. Williams, S.B. Etcheverry, E.J. Baran, Carbohydr. Res. 329 (2000) 41-47.

[39] D. Lin Vien, N.B. Colthup, W.F. Fateley, J.G. Grasselli, Infrared and Raman Characteristic Frequencies of Organic Molecules, Academic Press, Boston, 1991.

[40] E.G. Ferrer, P.A.M. Williams, Polyhedron 16 (1997) 3323-3325. 